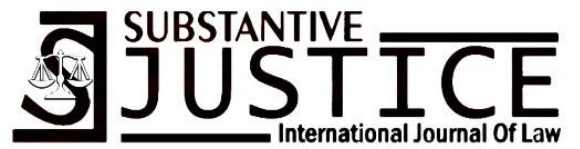

\section{Impeachment In The State System}

\author{
Nurwita Ismail \\ Faculty of Law, Universitas Gorontalo \\ nhurwita.ismail@gmail.com
}

\begin{abstract}
Impeachment In Constitutional System. This paper aims: To know and analyze how the impeachment arrangements in the Indonesian state administration system; To know and analyze how the legal process in impeachment mechanism before amendment and after an amendment of 1945 Constitution; by using Normative Method The study conducted in this research is the literature. Impeachment of the President and Vice President of his / her position is not new in the Indonesian state administration system. Both before the amendment and after the amendment of the 1945 Constitution. The 1945 Constitution of the amendment result has specified the provisions concerning the Impeachment of the President and Vice President as head of state. However, the mechanism of the impeachment process is determined in a constitutionally eliminative manner even though these reasons have a very broad interpretation and may be subjective, especially in a political institution of the DPR, by which there are several things to be considered in the impeachment process in Indonesia, such as the impeachment process in the House of Representatives Regional and process of Impeachment in the Constitutional Court. There is a need for the provision of legal products or the making of procedural law which regulates the impeachment of the President and Vice President.
\end{abstract}

Keywords: impeachment; constitutional system

\section{INTRODUCTION}

The state of the law is an idealized state by the founders of the nation as outlined in the general elucidation of the Constitution of the Republic of Indonesia on the system of state government which states that the State of Indonesia is based on the law (Rechtsstaat), not based on mere power (Machtsstaat). The Definition of a State The law is a state whose structure is best regulated in law so that all the powers of the instruments of his government are based on the law. The people shall not take any action that is contrary to law. The State of the Law is a State governed not by persons, but by law (state the not governed by men, but by laws). Therefore, an attitude, policy, action or behavior of state apparatus and citizens in the life of the nation and the state obey the rules or applicable law, it applies equally to every citizen, not the exception of the President as head of state and as head of government.

The governmental system adopted by Indonesia formally emphasizes the presidential system rather than the parliamentary system. One of the hallmarks of a presidential 


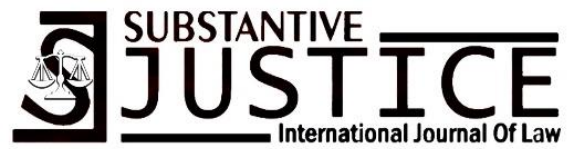

Volume I, Issue 1, March 2018 : 46 - 55

government is the term of office prescribed by the constitution. ${ }^{1}$ So with a fixed term presidential term fixed in the constitution, then the position of a president can be said to be strong or strong (strong executive). The result of the above characteristics is the creation of a stable government (executive stability). This is different from the parliamentary system which is executive instability because of executive dependence as a dependent variable to the political constellation in parliament (independent variable) ${ }^{2}$

The position of the president is held by an individual (personal). That means, the individual who served the president has a single power in running the government and its position strong and sturdy or not easy to drop. how great the power of the President as head of government to determine the direction of government during his tenure, should be from the power of course must be asked for accountability, both in the term of office and when will end the term of office. In addition to the responsibility for such authority or authority, the President as head of government may also be dismissed during his / her term of office, if deemed to violate the provisions contained in the Indonesian Constitution.

The President of the Republic of Indonesia holds the power of government ${ }^{3}$ so that the process of dismissal of the President / or Vice President can only be done after the constitutional process is passed through the Constitutional Court (MK) which will examine, hear and decide opinion of the House of Representatives that the President and/or Vice President have violated the law in the form of treason against the state, corruption, other serious criminal offenses, misconduct, or no longer qualify as President and/or Vice President. ${ }^{4}$

Impeachment is defined as a criminal justice process against a public official held before the Senate, called quasi-political court. An impeachment process begins with articles of impeachment, which functions similarly to an indictment of a criminal justice. The impeachment process is one of the powers held by the legislature as a form of the parliamentary control function over the conduct of every public official who has been given the mandate by the people to carry out their duties and obligations. If the public official performs a violation during his / her term of office in constitutional or positive law, then the person concerned may be faced with an impeachment process leading to the discharge of his / her position. Impeachment is designed as an instrument to "reprimand" misconduct, misuse and violation of the public trust of persons holding public office. ${ }^{5}$

\footnotetext{
${ }_{1}^{1}$ Arend Lijphart, 1994, Sistem Pemerintahan Parlementer dan Presidensial, PT. Raja Grafindo Persada, Jakarta, p. 5. ${ }^{2}$ Ibid

${ }^{3}$ Pasal 4 Ayat (1) Undang-undang Dasar Negara Republik Indonesia,

${ }^{4}$ Pasal 7B Ayat (1) Undang-undang Dasar Negara Republik Indonesia,

${ }^{5}$ Raoul Berger. Impeachment: The Constitutional Problems (Cambridge: Harvard University Press, 1974)
} 


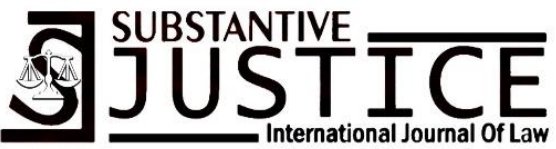

After Amendment IV of Indonesia's constitution, Indonesia has a new rules for impeachment mechanism. In addition to the clarity of its processes and mechanisms, the impeachment is stipulated in the Indonesian constitution ${ }^{6}$ also seem more juridical than political. Institutionally the impeachment issue of its jurisdiction is held by the Constitutional Court through Law no. 24 In 2003, then in the final process, later political decisions are in the hands of the People's Representative Council.

Indonesia during its constitutional history has already toppled the president twice. This historical experience has caused controversy over the process and the mechanisms and reasons used in bringing down a president. From the process of the collapse of the two Presidents of Indonesia, and the reasons used with the various dialectics of the State administration, in terms of the system of government adopted by Indonesia, there is a confusion between the Presidential government system and the parliamentary government system. The Impeachment process of the two Presidents of the Republic of Indonesia is the time of President Soekarno and President Abdurrahman Wahid.

Two impeachment executions occurring in Indonesia have resulted in the confusion of the state administration from the juridical side and not infrequently causing both material and immaterial damage when viewed from the social aspect of society. Therefore it is time for Indonesia to have a rule and mechanism (rule of the game) that clearly there is the various process of state administration, especially in the case of impeachment. Based on the description of the background that has been described above, the problems that the author discussed are formulated as follows: How the impeachment arrangements in the Indonesian state administration system and how the legal process in the impeachment mechanism before the amendment and after amendments to the 1945 Constitution. Which details will be described in the next chapter. In order to be more directed this paper, the authors determine in the formulation of the problem such as (1) How the impeachment arrangement in the Indonesian state administration system, (2) What is the legal process in the impeachment mechanism before the amendment and after the amendment of the constitution in Indonesia?

\section{METHOD}

Legal research is a scientific activity, based on methods, systematics, and certain thoughts, which aims to study something or some specific legal phenomena by analyzing them. ${ }^{7}$

\footnotetext{
${ }^{6} \mathrm{Ibid}$

${ }^{7}$ Soeryono Soekanto, Pengantar Penelitian Hukum, (Jakarta: UI Press, 1981) p. 43.
} 


\section{凫}

Research in this paper using normative legal research model as well as in research other legal studies. The study conducted in this research is literature. Method (method) that can be done is document study (documentary study). That is, in this study will be reviewed critically every literature such as legislation, books, articles, journals, magazines, and other materials related to the issue of impeachment (impeachment) in Indonesia.

Because this research is normative law research, the data collected is secondary data. Secondary data is obtained from legal materials that bind and related to the object of this study, namely: Stage analysis and presentation of data occupy a fairly decisive position in this study. The data collected, both primary, secondary, tertiary legal materials and information from experts are analyzed using theoretical or conceptual instruments as in the framework to discuss or provide answers to this research problem. Considering the target data is juridical, the data analysis is done with qualitative analysis and the results are expressed in descriptive form.

Data analysis is done in a process, ie the implementation has been done since the data collection is done intensively until after the data collection is completed. The process of this analysis is done almost simultaneously with the interpretation of data done immediately without having to wait for the amount of data collected. Before analyzed, the data obtained then processed by first doing selection and clarification in a logical, systematic, and juridical. This research is a normative legal research that is descriptive, then the data are analyzed qualitatively.

\section{ANALYSIS AND DISCUSSION}

\section{setting the impeachment in Indonesian state administration system}

Indonesia is a state of law, as stated in the Indonesian Constitution ${ }^{8}$ thus the state is obliged to uphold the supremacy of law (Supremacy Of The Law) as one of the joint states of politics, in addition to the joints of democracy, the joints of social justice and others as mandated by the constitution, the existence of the constitution evolved from the idea of a limited government (limited government) ${ }^{9}$ or understand constitutionalism so that power is not misused. Sri Soemantri asserted that the substance of constitution content is: the existence of guarantee on the citizen's human rights; the establishment of a constitutional structure which is fundamental; the division and restriction of constitutional duties which are also fundamental.

\footnotetext{
${ }^{8}$ Amandemen III Konstitusi Indonesia

${ }^{9}$ K.C Wheare, Modern Constitution (London: Oxford University Press, 1975), p. 7
} 


\section{凫}

Provisions regarding impeachment against the President and/or Vice President are usually regulated in the constitution used by a country. The explanation of what reasons justify impeachment is generally described in the constitution. This is because impeachment is an important and crucial part of a state's constitutional system. That is why in almost all democratic countries the provision of impeachment is clearly and firmly set out in the constitution.

After the constitutional amendment, there are three (3) state institutions that play an important role in the process of dismissing the President and/or Vice President. The three state institutions are the House of Representatives (DPR), the Constitutional Court (MK) and the People's Consultative Assembly (MPR). Of course, the authority owned by each state institution above is very different. In short, however, the combination of the three (3) state institutions above is nothing but a combination that plays an important role in dismissing the President and/or Vice President through the legal process and dismissal of the president through the political process. Through the political process in the Parliament then brought to the table of law in the Constitutional Court and returned again to the political decisions in the MPR.

In the United States, impeachment arrangements are provided in Article 2 Section 4 which states, "The President, Vice President, and all civil officers of the United States, shall be removed from office on the impeachment for and conviction of treason, bribery, or other high crimes and misdemeanors ". This article then inspires the constitutions of other countries in impeachment arrangements including Article 7A of the Third Amendment of the 1945 Constitution which states that the President and / or Vice President may be dismissed in his term by the People's Consultative Assembly (MPR) on the proposal of the House of Representatives if proven to have committed a violation of the law in the form of treason against the state, corruption, bribery, other serious criminal acts or disgraceful acts or if proven to be ineligible as President and/or Vice President. ${ }^{10}$

The presence of the Constitutional Court is intended to show that in Indonesia in the case of impeachment the President embraces a mixed system, namely the system of "impeachment" and "forum previlegiatum. If extracted from various constitutions in the world, theoretically the way of the fall of President and/or Vice President according to the constutional amendment result using mixed system between impeachment system and previlegiatum forum system. By impeachment, it is intended that the President be imposed by a political institution that reflects the representatives of all the people through political judgments and decisions with

${ }^{10} \mathrm{lbid}$

Impeachment In The State System 


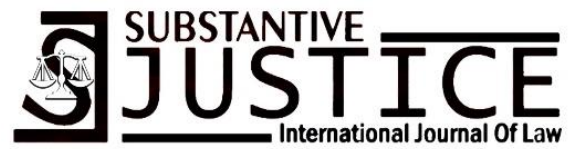

Volume I, Issue I, March 2018 : 46 - 55

strict conditions and mechanisms. While the previlegiatum forum is the imposition of the President through a special court of state administration which is essentially a violation of the severe laws prescribed in the constitution by a judgment also ". ${ }^{11}$

The impeachment system here means political judgment and decision in the DPR, while the previlegiatum forum is meant to be a constitutional court by the Constitutional Court. So as outlined above, the Indonesian constitution regulates impeachment in two stages.

\section{The Legal Process in Impeachment Mechanism before and After Amendment}

Prior to the amendment of the 1945 Constitution, the President and/or Vice President may be dismissed for political, non-juridical reasons. This is unusual in countries with presidential government systems. Therefore, the Third Amendment of the 1945 Constitution contains the stipulation of the termination of the President and/or Vice President in his tenure solely based on juridical reasons and refers only to the normative-limiting provisions mentioned in the Constitution. In addition, the process of dismissal can only be made after the constitutional process is passed through the Constitutional Court which will examine, hear and decide the opinion of the House of Representatives that the President and/or Vice President have violated the law in the form of treason against the state, corruption, bribery, another serious criminal, a disgraceful act, or no longer qualifies as President and / or Vice President.

The possibility of dismissal of the President and/or Vice President in his / her term of office by the MPR on the proposal of the House is what is technically constituted by the term impeachment. However, the next issue, the provisions on impeachment contained in the constitution does not further regulate technical issues, so at the moment there is still a proper formulation of it.

Parliament will use impeachment mechanisms to process high-ranking officials and powerful individuals associated with corruption, or other matters that do not constitute ordinary court powers. In practice, The House of Commons acts as a Grand Jury who decides whether to impeach an official or not. If the official is impeached, then The House of Lords will judge him. If found guilty, the officer shall be punished according to the stipulated provisions, including his / her position. Indeed the impeachment process is an instrument to prevent and overcome the abuse of power from the holder.

\footnotetext{
${ }^{11}$ Mahfud MD. Perdebatan Hukum Tata Negara Pasca Amandemen Konstitusi. Jakarta: Pustaka LP3ES Indonesia, 2007
} 


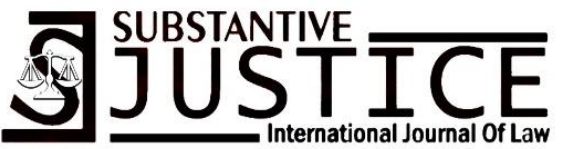

Volume 1, Issue 1, March 2018 : 46 - 55

When the constitution was drafted in 1787, in Philadelphia, Pennsylvania, the fathers of the United States had seen the tendency of leaders to become corrupt when in power. In addition to corrupt, the leaders are also trying to stay in control as long as possible. Therefore, they created a constitution based on the foundations of checks and balances that can minimize the abuse of power. Impeachment is designed as an instrument to "reprimand" misconduct, misuse and violation of the public trust of persons holding public office.

The process of impeachment in Indonesia through the process in three state institutions directly, the first process is in the DPR by proposing that the President and/or Vice President have made a betrayal of the state or bribe or other serious criminal acts, or a disgraceful act, even the DPR is authorized states that the President or Vice President no longer qualifies as a state leader. Through its supervision, the House of Representatives investigates the allegation that there has been an action that is categorized in the impeachment grounds, after the process in the House of Representatives is completed in which the plenary session of the House of Representatives agrees to declare that the President or Vice President has taken action as the reason for impeach, the decision of the plenary session shall be brought to the Constitutional Court. Before finally the Impeachment process is handled by the MPR to get the final word as a determinant of the fate of the President and/or Vice President.

This condition was preceded by the request of the Parliament to the Constitutional Court after being supported by at least $2 / 3$ of the total members of the People's Legislative Assembly (Article 7 B Paragraph (3) of the Constitution). Subsequently pursuant to Article 80 paragraph (2) of Law Number 24 / 2003 regarding the Constitutional Court requires that the House impeachment shall clearly state in its petition regarding the allegation that the President and/or Vice President have committed a violation of the law in the form of: country; 2. corruption, bribery; 3 . other serious criminal offenses, or disgraceful acts; 4 . and/or the President shall no longer qualify as President and/or Vice President based on the Constitution. The People's Legislative Assembly in its petition shall be obliged to include the decision of the People's Legislative Assembly and the decision-making process concerning the opinion of the People's Legislative Assembly, minutes and / or minutes of DPR, accompanied by evidence of the allegations expressed in the minutes of the opinion of the People's Legislative Assembly. The Constitutional Court submits a request already recorded in the Book of Constitutional Case Registration to the President within a period of no more than 7 (seven) working days after the application is recorded in the Constitution Case Registration Book. ${ }^{12}$

\footnotetext{
${ }^{12}$ Pasal 80 ayat (3) Undang-undang Nomor 24 Tahun 2003. Menurut Pasal 81 Undang-undang Nomor 24 Tahun 2003 Mahkamah Konstitusi
}

Impeachment In The State System 


\section{凫}

If the Constitutional Court decides that the President and/or the Vice President have not been proven to have violated the Law in the form of a state treason, corruption, bribery, other serious criminal offense, or disgraceful acts and/or proven to be no longer eligible as President and/or Vice President, the ruling declared the DPR's request to be rejected (Article 83 paragraph (3) of Law Number 24 of 2003). The Constitutional Court is obliged to examine, hear, and decide as fairly as possible the opinion of the People's Legislative Assembly within 90 (ninety) days of the time the application is recorded in the Registration of Constitutional Cases $^{13}$. The decision of the Constitutional Court regarding the opinion of the People's Legislative Assembly shall be submitted to the Parliament and the President and/or Vice President. ${ }^{14}$

On the other hand, if the Constitutional Court decides that the President and/or the Vice President have proven to have committed a law violation, or a disgraceful act, and or proven to be no longer eligible as President and / or Vice President, the Parliament shall hold a plenary session to forward the proposal of dismissal of the President and / MPR (Article 7 B paragraph (5) of the Indonesian Constitution). The MPR is obliged to convene a session to decide upon the proposal of the DPR no later than 30 (thirty) days after receiving the proposal (Article 7 B 96) of the Indonesian Constitution). The MPR's decision on the proposed dismissal of the President and/or Vice President shall be taken in the MPR Plenary Session which shall be attended by at least $3 / 4$ of the total members and approved by at least $2 / 3$ of the total members present, after the President and / or Vice-President are given the opportunity to submit an explanation in the MPR Plenary Session (Article 7 B paragraph (7) of the Indonesian Constitution).

The decision of the MPR to dismiss the President and/or Vice President during the term of office is a political decision (politieke beslissing), not a judicial decision (judicial vonnis). The dismissal of the President and/or Vice President in his / her term of office shall be the constitutional authority of the MPR, not the jurisdiction of the judiciary (rechspraak). Although the Constitutional Court has ruled that the opinion of the House of Representatives regarding the violation of the law by the President and/or Vice President has been proven, the MPR may pass other decisions along the political considerations (politieke overweging) in the Plenary Session of the People's Consultative Assembly to receive both the explanation put forward by

\footnotetext{
${ }^{13}$ Pasal 7 B ayat (4) UUD NRI Tahun 1945 juncto Pasal 84 Undang-undang Nomor 24 tahun 2003 Mahkamah Konstitusi

${ }^{14}$ Pasal 85 Undang-undang Nomor 24 Tahun 2003. Menurut Pasal 81 Undang-undang Nomor 24 Tahun 2003
} Mahkamah Konstitusi

Impeachment In The State System 
the President and / or vice president so that the meeting views the President and / or Vice President need not be dismissed.

MPR Meetings first give an opportunity to the President and/or Vice President to give an explanation before the plenary session handed down the verdict (vide Article 7 B Paragraph (7) of the 1945 Constitution of the Republic of Indonesia). The explanation referred to in the constitution article is essentially a defensive measure for the President and/or Vice President. It does not mean that the decision of the MPR overrides the decision of the Constitutional Court, but the dismissal of the President and/or Vice President in his term is indeed constitutioneeele bevoegheden of the MPR. In the meantime, the MPR Plenary Session which dismisses the President and/or Vice President is limited to dismissing the President and/or Vice President from the public office of the head of state government, in the meaning of removal from the office, not entering the realm of investigation and criminal prosecution against the President and/or vice-president who is laid off. Political rulings (politics beslissing), not part of the process of investigation (opsporing) and prosecution. ${ }^{15}$

\section{CONCLUSION}

The amendment of the Constitution which has had an impact on the amendment of the state administration system has revolutionized the structure and mechanism of the state administration. The model of government system has changed where the Presidential government system is followed by the mechanism of direct election of President and Vice President. The power to form Law has shifted from President to DPR. The amendment of the Constitution has made the House be a very powerful institution, not to mention very powerfull because the House holds many important roles in the course of the constitutional system. The cornerstone of such an important authority in the House of Representatives is to depart from the need for strong control mechanisms resulting from past authoritarian regime lessons held by government authorities.

That the State of the Republic of Indonesia as mandated by the 1945 Constitution and Law no. 24 of 2003 on the Constitutional Court to know what is called impeachment (permakzulan). The institutions involved in this process are the People's Legislative Assembly acting as proponents, then the Constitutional Court of the Republic of Indonesia acting as the proxy party and the People's Consultative Assembly (MPR) acting as the final decision-maker through the Special Session.

15 Djanggih, Hardianto, et al, 2017. "Bahasa Hukum (legal Language)". INA-Rxiv. October 23. doi:10.17605/OSF.IO/Z8NM4.

Impeachment In The State System 


\section{凫}

\section{Volume I, Issue I, March 2018 : 46 - 55}

\section{SUGGESTION}

There must always be checks and balances, which are implemented in a judicial mere legal enforcement, the role of the Constitutional Court is required in accordance with its authority as regulated by the Law against the application of Impeachment of the President and/or Vice President. Implementation Impeachment must be maintained if you want a system with the principles of the legal state that aspired.

\section{REFERENCE}

Arend Lijphart, 1994, Sistem Pemerintahan Parlementer dan Presidensial, PT. Raja Grafindo Persada, Jakarta.

Black Carles L., 1998, Impeachment, a Hand Book., Yale University Press, New Haven and London.

Manan, Bagir, Menyongsong Fajar Otonomi Daerah, ctk. Pertama, PSH Fakultas Hukum UII, Yogyakarta, 2001.

Mahfud MD. Perdebatan Hukum Tata Negara Pasca Amandemen Konstitusi. Jakarta: Pustaka LP3ES Indonesia, 2007

Djanggih, Hardianto, et al, 2017. "Bahasa Hukum (legal Language)". INA-Rxiv. October 23. doi:10.17605/OSF.IO/Z8NM4.

Raoul Berger. Impeachment: The Constitutional Problems (Cambridge: Harvard University Press, 1974)

Soeryono Soekanto, Pengantar Penelitian Hukum, (Jakarta: UI Press, 1981).

Sri Soemantri, Prosedur dan Sistem Perubahan Konstitusi, Edisi Revisi, (Bandung, Alumni ,2006).

K.C Wheare, Modern Constitution (London: Oxford University Press, 1975)

Fatkhurohman dan Miftachus Sjuhad, Memahami Pemberhentian Presiden (Impeachment) Di Indonesia Studi Perbandingan Pemberhentian Presiden Soekarno dan Presiden Abdurrahman Wahid), Jurnal Konstitusi, Vol. III, No.1, Juni 2010,

Abdul Rahman, IMPEACHMENT DALAM UUD 1945 PASCA AMANDEMEN (Analisis Terhadap Proses Hukum Vis-a-Vis Proses Politik), Jurnal Hukum Diktum, Volume 14, Nomor 1, Juli 2016: 89 - 105

\section{Undang-Undang}

Amandemen I - IV Undang-Undang Dasar Negara Republik Indonesia Tahun 1945.

UU No. 24 Tahun 2003 tentang Mahkamah Konstitusi. 